\title{
Neuroprotective Effect of Petroleum Ether, Methanolic and Aqueous Extracts of Fruits of Benincasa hispida on Lipofuscinogenesis and Fluorescence Product in Brain of D-galactose Induced Aging Accelerated Mice
}

\author{
Digambar Balkrishna Ambikar ${ }^{1, *}$, Guru Prasad Mohanta ${ }^{2}$ \\ 'Department of Pharmacology, Indira College of Pharmacy, Tathawade, Pune, Maharashtra, INDIA. \\ ${ }^{2}$ Department of Pharmacy, Annamalai University, Annamalai Nagar, Tamil Nadu, INDIA.
}

\begin{abstract}
Background: Aging is one of the major factors of development of neurodegenerative disorder and also involved in gradual learning and memory loss. In recent years discovery of antiaging drugs is one of the important topic of research. Many plant drugs proved to be reliable treatment for aging associated changes. Aim: The present investigation was aimed at determining the neuroprotective effect of petroleum ether (BHP), Methanolic (BHM) and aqueous extract (BHA) obtained from Benincasa hispida by the measurement of fluorescence product and biochemical parameter like lipid peroxidation, catalase activity and glutathione peroxides activity in the brains of D-galactose induced aging accelerated female albino mice. Methods: D-galactose administration is a well-known model to accelerate normal aging. D-galactose $(0.5 \mathrm{ml} 5 \%)$ was administered for 15 days and accumulation of fluorescence product and lipofuscin granule in cerebral cortex was evaluated. Moreover lipid peroxidation activity and the antioxidant enzymes like glutathione peroxides and catalase activity in cerebral cortex were also evaluated. Furthermore brains of mice subjected to histopathology studies for evaluation of lipofuscin granules. Results: Co-treatment of D-galactose with BHP, BIM and BIA (100 mg/kg, po) reduced the fluorescence product accumulated in the cerebral cortex. BIM and BHA was protective against D-galatose-induced accelerated aging by reducing lipid peroxidation and restoring the enzymatic activity of glutathione peroxidase and catalase. Moreover BIM was also showed decreased accumulation of lipofuscin granules. Conclusion: In conclusion, BIM and BIA were found to be an effective neuroprotective reagent which could reverse D-galactose-induced oxidative damage and acceleration of aging.
\end{abstract}

Key words: Neuroprotection, Aging accelerattion, Fluorescence product, Lipid peroxidation, Lipofuscin granules, Benincasa hispida.

\section{INTRODUCTION}

Aging is natural phenomenon which is always associated with diverse chronic diseases, including neurodegenerative disorders, cancer and cardiovascular diseases. ${ }^{1,2}$ Aging also associated with gradual, incremental loss of cognitive and motor performances. Moreover normal life of patient is significantly affected by rapid cognitive decline, due to age dependent neurological disorders. ${ }^{3}$ With the increasing elderly population in the world, aging has already become an important public issue. ${ }^{4}$ Recent reports indicate that the chronic administration of $\mathrm{D}$-galactose is responsible for aging acceleration and also influenced the age related cognitive decline in mice., ${ }^{5,6}$ D-galactose causes the formation of advanced glycation end-products (AGEs)
Submission Date: 11-12-2019; Revision Date: 22-06-2020; Accepted Date: 12-04-2021

DOI: 10.5530/ijper.55.2s.124 Correspondence: Dr. Digambar B Ambikar Department of Pharmacology, Indira College of Pharmacy, Tathawade, Pune-411033, Maharashtra, INDIA. Phone: +919975683992 Email id: pharmascholy@ gmail.com

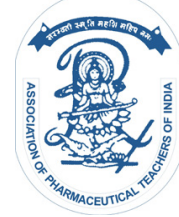

www.ijper.org 
in vivo, resulting in oxidative stress which in turn leads to accumulation of Reactive Oxygen Species (ROS) and stimulation of free radical production. ${ }^{7}$ Repeated injection of D-galactose in animals is known to cause alterations in biochemical markers, loss in propagating ability, retrograde changes in neural cells and memory impairments which are nothing but the aging like symptoms. ${ }^{8,9}$ The D-galactose induced excessive formation of ROS followed by neuronal damage, chiefly manifested as decline in learning and memory capacity is widely cited model of neurodegeneration associated with aging acceleration. ${ }^{10}$ The oxygen metabolism of D-galactose produces many ROS, which may result in direct or indirect impairment of learning and memory. ${ }^{9}$ Various in vivo and in vitro studies have reported that, D-galactose is a reducing sugar that readily reacts with the free amine groups of neuronal proteins and neuropeptides to form advanced glycation end-products (AGEs). These AGEs undergo chemical oxidation and degradation via AGE-receptor binding and activation of signaling pathways to form free radicals and cause oxidative stress. In addition, the glycated protein produces 50 fold more free radicals than non glycated protein at the physiological $\mathrm{pH}$, which in turn contribute to increase oxidative stress and thereby damage the micromolecules and cell organelles particularly the mitochondria. ${ }^{10}$ These affect the mitochondrial functioning causing less production of the ATP and more production of the free radicals, leading to an extra burden on lysosomes for the degradation of autophagocytosed and damaged micromolecules and mitochondria. ${ }^{11}$

Though there is continuous advancement in current pharmacotherapy for the neurodegenerative disorders still there is lack of effective and widely applicable pharmacological treatments which may explain a growing interest in the traditional medicines. ${ }^{12}$ The use of medicines from plant sources has increased globally due to their lower adverse effects, price and good efficacy in the majority of human illnesses. ${ }^{13,14}$ Benincasa hispida $(\mathrm{BH})$ is used as food in different part of India and other tropical countries and belongs to the family Cucurbitaceae. ${ }^{15}$ In Ayurveda, $\mathrm{BH}$ is recommended for treatment of peptic ulcer, hemorrhages from internal organs, epilepsy and other nervous disorders. ${ }^{16,17} \mathrm{BH}$ was also reported for its histamine release inhibition activity in the rat exudates cell, where histamine release was induced by antigen-antibody reaction. ${ }^{18}$ Alcoholic and petroleum ether extract of $\mathrm{BH}$ exhibited antiulcerogenic effect. $\mathrm{BH}$ probably has a $\mathrm{CNS}$ component in prevention of stress induced ulceration. ${ }^{19}$ Aqueous extract of seeds of $\mathrm{BH}$ also showed immunopotentiator activity. The juice of $\mathrm{BH}$ was found to be effective against morphine withdrawal symptoms. ${ }^{20}$ Researcher also reported anxiolytic activity of $\mathrm{BH} \cdot{ }^{21}$ In our earlier reports $\mathrm{BH}$ showed inhibition of locomotor activity, nootropic, anxiolytic and analgesic activity. Moreover $\mathrm{BH}$ also showed potentiation of haloperidol induced catalepsy. ${ }^{22}$ The present investigation was aimed at determining the neuroprotective activity of petroleum ether (BHP), Methanolic (BHM) and aqueous extract (BHA) obtained from Benincasa hispida by the measurement of fluorescence product and biochemical parameter like lipid peroxidation, catalase activity and glutathione peroxides activity in the brains of D-galactose induced aging accelerated female albino mice.

\section{MATERIALS AND METHODS}

\section{Plant material}

The plant material (fruits of Benincasa hispida) was collected from Pune region of Maharashtra, India and was authenticated by botanical survey of India.

\section{Preparation and standardization of Extract}

Petroleum ether extract (BHP), methanolic extract (BHM) and aqueous extracts (BHA) were prepared by succsessive extraction method. The fruit pulp of $\mathrm{BH}$ were dried in shade and coarsely powdered. The powder was successively extracted with petroleum ether followed by methanol in a soxhlet apparatus. Powder remaining after methanolic extraction was subjected to aqueous extraction..$^{23}$ The aqueous extract was prepared by maceration with distilled water for $24 \mathrm{hr}$. The extracts were concentrated under reduced pressure and were stored at $8-10^{\circ} \mathrm{C}$ throughout the study. The yield of BHP, BHM and BHA were $4.2 \% \mathrm{w} / \mathrm{w}, 3.2 \% \mathrm{w} / \mathrm{w}$ and $5.1 \% \mathrm{w} / \mathrm{w}$ respectively.

Preliminary thin layer chromatography study was carried out for checking the presence of phyto-constituents such as beta-sitosterol, lupeol, isovitexin, isomultiflorinol, cucurbitacin and other amino acid etc. which have been reported to present in $\mathrm{BH}$. Further quantitative estimation of phyto-constituents using high pressure thin layer chromatography (HPTLC) fingerprinting was also carried out using RP-18 silica as follows. ${ }^{24}$

Betasitosterol in BHP, Petroleum ether: Acetonitrile: Methanol (1:2:2)

Lupeol in BHP, Benzene: Ethyl acetate (9.5: 0.5)

Isovitexin in BHM, Ethyl acetate: n-butanol: Water $(2: 1: 3)$

\section{Chemicals and drugs}

D-galactose, 5, 5-dithiobisnitrobenzoic acid (Loba chemicals, Mumbai, India), thiobarbituric acid, 
trichloroacetic acid, ascorbate (SD Fine Chemical, Mumbai, India) and glutathione (Ozone, Mumbai, India) were used.

\section{Animals}

Six months old female Swiss albino mice (18-22g) certified as healthy by a veterinary physician were used. The female mice were reported to be ideal for D-galactose model and are more susceptible towards D-galactose induced changes in brain as compared to male mice. ${ }^{10}$ These mice were maintained at $25^{\circ} \mathrm{C} \pm 2{ }^{\circ} \mathrm{C}$ and $45-55 \%$ $\mathrm{RH}$ and under standard environmental conditions (12:12 h L:D cycle). These mice had free access to food and water. Institutional Animal Ethics Committee (IAEC) of Marathwada Mitra Mandals College of pharmacy has approved the protocol (CPCSEA/IAEC/PC-10/12) and entire study has carried out as per standard guideline of IAEC.

\section{Acute toxicity test}

Mice were subjected to acute oral toxicity study as per guidelines suggested by the Organization for Economic Co-operation and Development. ${ }^{25}$ The mice were observed continuously for $2 \mathrm{hr}$ for behavioral and autonomic profiles and for any sign of toxicity or mortality up to 7 days.

\section{D-galactose treatment}

60 female albino mice were divided in to five groups of 12 each. First group served as control and received $0.5 \mathrm{ml}$ saline per day for 15 days. Second group mice were injected with $0.5 \mathrm{ml} \mathrm{5 \%} \mathrm{D}$-galactose (sc) per day for 15 days as served as aging accelerated group. The mice of third, fourth and fifth group were injected (sc) with a daily doses of $0.5 \mathrm{ml} \mathrm{5 \%} \mathrm{D}$-galactose plus BHP, BHM and BHA $100 \mathrm{mg} / \mathrm{kg}$ (po). The dose was selected from our previous neurobehavioral study of $\mathrm{BH} .{ }^{22} \mathrm{On}$ $15^{\text {th }}$ day, 60 min after the doses of BIP, BIM and BIA and D-galactose mice were sacrificed. From each group six mice were subjected for biochemical estimation of lipofuscin content, lipid peroxidation, glutathione peroxides and catalase activity. Remaining six mice were subjected to histopathological examination. 5,6,10

\section{Measurement of fluorescence}

Lipofuscin contents from whole cerebral cortex were extracted in chloroform: methanol mixture $(2: 1 \mathrm{v} / \mathrm{v})$ and fluorescence was measured on photofluorometer using $1 \mu \mathrm{g}$ of quinine sulfate/ml of $0.1 \mathrm{~N}$ sulfuric acid as standard and $0.1 \mathrm{~N}$ sulfuric acid as blank. ${ }^{5,6,10}$

\section{Antioxidant activity}

As a measure of lipid peroxidation, malonaldialdehyde (MDA) levels was estimated according to method of Kakkar et al. ${ }^{26}$ by measuring thiobarbituric acid reactive substances (TBARS). Initially the color developed was read at $532 \mathrm{~nm}$ using spectrophotometer and expressed as $\mathrm{nM} / \mathrm{mg}$ of protein.

Activities of glutathione peroxidase (GPx) was estimated; ${ }^{27-29}$ the color developed was read at $420 \mathrm{~nm}$ using spectrophotometer and expressed as $\mathrm{U} / \mathrm{mg}$ of protein.

The activity of catalase (CAT) was measured according to the method of Claiborne (1991) $)^{30}$ and the protein content of brain tissue was estimated by following the method of Lowry et al. ${ }^{31}$

\section{Histopathological examination}

The mice were sacrificed by decapitation and brains were taken out. Individual entire brain was fixed in neutral buffered 10\% formalin for $24 \mathrm{hr}$. Paraffin blocks were prepared by microtechnique and saggital sections of $5 \mu \mathrm{m}$ forebrain were prepared using rotary microtome (INCO, Ambala, India). This section then stained with ZeilNeelson Carbolfuscin method and microscopical examination was carried out under $40 \mathrm{x}$ lens. ${ }^{32}$

\section{Statistical analysis}

The data were expressed as mean \pm SE. One way ANOVA followed by Tukey's post hoc test was performed by using GraphPadInStat version 3.01,32, GraphPad Software, San Diego California, USA.

\section{RESULTS}

\section{Phytochemical Analysis}

Presence of beta-sitosterol and lupeol was found in thin layer chromatographic study of BHP while presence of isovitexin was found in BHM.

The $6.18 \% \mathrm{w} / \mathrm{w}$ of beta-sitosterol and $2.23 \%$ of lupeol was found in HPTLC study of BHP. The level of isovitexin in $\mathrm{BHM}$ was found to be $0.78 \%$.

\section{Acute toxicity test}

$\mathrm{BHP}, \mathrm{BHM}$ and BHA was found safe up to the dose of $2 \mathrm{gm} / \mathrm{kg}$. All three extract reported non-significant sedation above the dose of $500 \mathrm{mg} / \mathrm{kg}$.

\section{Fluorescence content}

The biochemical extraction of fluorescence product in vehicle treated control mice and 15 days $\mathrm{D}$ galactose 
treated (ageing accelerated) mice was $0.45 \pm 0.008$ and $1.29 \pm 0.022 \mathrm{ug} / \mathrm{mg}$ of protein respectively and there by showed significant $(P<0.001)$ increase in the fluorescence product in $\mathrm{D}$ galactose treated mice. While in BHP, BHM and BHA co-treated ageing accelerated mice it were $0.992 \pm 0.029,0.88 \pm 0.01$ and $0.56 \pm 0.03 \mathrm{ug} /$ mg of protein (Table 1 ).

\section{Assay of lipid peroxidation}

The MDA levels in cerebral cortex of vehicle treated control mice and 15 days $\mathrm{D}$ galactose treated (ageing accelerated) mice was $1.49 \pm 0.02 \mathrm{nM} / \mathrm{mg}$ of protein and $2.19 \pm 0.04 \mathrm{nM} / \mathrm{mg}$ of protein respectively and there by showed significant $(P<0.001)$ increase in MDA levels of ageing accelerated mice. In BHP, BHM and BHA co-treated mice the MDA levels was significantly $(P<0.01)$ decreased to $1.876 \pm 0.078,1.59 . \pm 0.05$ and $1.8197 \pm 0.03 \mathrm{nM} / \mathrm{mg}$ of protein as compare to ageing accelerated mice (Table 1).

\section{Glutathione peroxidase activity}

The GPx activity levels in cerebral cortex of control mice were found to be $31.83 \pm 1.47 \mathrm{mU} / \mathrm{mg}$ of protein. In ageing accelerated mice GPx levels was significantly $(P<0.001)$ decreased to $25.35 \pm 0.92 \mathrm{mU} / \mathrm{mg}$ of protein. While significant $(P<0.01)$ attenuation in GPx levels was found in BHP, BHM and BHA co-treated mice as compare to ageing accelerated mice. In BHP, BHM and BHA the GPx activity levels was $27.71 \pm 0.36,28.59$ $\pm 0.49 \mathrm{and} 25.18 \pm 1.20 \mathrm{mU} / \mathrm{mg}$ of protein (Table 1).

\section{Catalase activity}

A significant $(P<0.001)$ decline in the catalase activity levels in cerebral cortex of ageing accelerated mice was found. In aging accelerated group catalase activity level was $0.51 \pm 0.02 \mathrm{umol} / \mathrm{min} / \mathrm{mg}$ of protein as compare to control mice $0.99 \pm 0.06 \mathrm{umol} / \mathrm{min} / \mathrm{mg}$ of protein. Where as in BHP, BHM and BHA co-treated mice the catalase activity levels was significantly $(P<0.01)$ increased to $0.56 \pm 0.01,0.693 \pm 0.02$ and $0.67 \pm 0.01 \mathrm{umol} / \mathrm{min} / \mathrm{mg}$ of protein as compare to ageing accelerated mice (Table 1).

\section{Histopathology}

From histopathology studies it was revealed that, there is increased accumulation of lipofuscin granules in the brain of D-galactose treated aging accelerated group as compared to control (Figure 1 and 2). BHA co-treated group showed decreased accumulation of lipofuscin granules as compared to aging accelerated group (Figure 3). No decline in lipofuscin granules was found in $\mathrm{BHP}$ and BHM co-treated group as compared to aging accelerated group (Figure 4 and 5).

\section{DISCUSSION}

Neurodegeneration is often age-associated and generally a result of process of aging. Aging is due to decline in

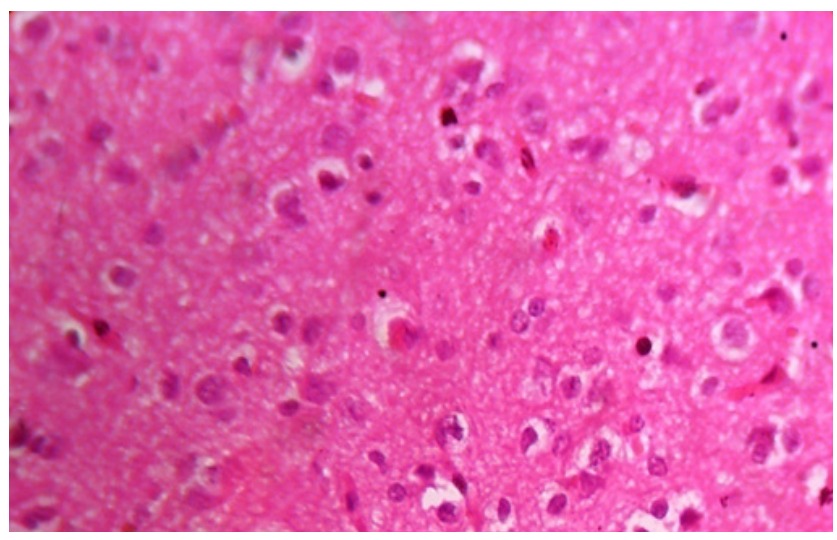

Figure 1: Saggital section of cerebral cortex of control mice demonstrating normal distribution of lipofuscin granules.

\begin{tabular}{|c|c|c|c|c|c|}
\multicolumn{6}{|c|}{ Table 1: Effect of BHP, BHM and BHA on fluorescence product, lipid peroxidation, glutathione } \\
peroxidase and catalase activity. \\
\hline $\begin{array}{c}\text { SL } \\
\text { No }\end{array}$ & Group & $\begin{array}{c}\text { Fluorescence } \\
\text { product } \\
\text { (ug/mg of protein) }\end{array}$ & $\begin{array}{c}\text { TBARS } \\
\text { (nM/mg of } \\
\text { protein) }\end{array}$ & $\begin{array}{c}\text { GPx } \\
\text { (U/mg of protein) }\end{array}$ & $\begin{array}{c}\text { CAT } \\
\text { ( } \mu \text { mol/min/ } \\
\text { mg of protein) }\end{array}$ \\
\hline 1 & Control & $0.456 \pm 0.008$ & $1.49 \pm 0.02$ & $31.83 \pm 1.47$ & $0.99 \pm 0.06$ \\
\hline 2 & $\begin{array}{c}\text { D galactose treated } \\
\text { Ageing acc. Group }\end{array}$ & $1.29 \pm 0.022^{* * *}$ & $2.19 \pm 0.04^{*}$ & $25.35 \pm 0.92^{*}$ & $0.51 \pm 0.02^{*}$ \\
\hline 3 & $\begin{array}{c}\text { BIP + D-galactose } \\
\text { treated (Gr. III) }\end{array}$ & $0.992 \pm 0.029$ & $1.876 \pm 0.078$ & $27.71 \pm 0.36$ & $0.56 \pm 0.01$ \\
\hline 4 & $\begin{array}{c}\text { BIM + D-galactose } \\
\text { treated (Gr. IV) }\end{array}$ & $0.88 \pm 0.01^{\#}$ & $1.59 . \pm 0.05^{\# \#}$ & $28.59 \pm 0.49^{\# \#}$ & $0.693 \pm 0.02^{\# \#}$ \\
\hline 5 & $\begin{array}{c}\text { BIA + D-galactose } \\
\text { treated (Gr. V) }\end{array}$ & $0.56 \pm 0.03^{\# \#}$ & $1.8197 \pm 0.03^{\#}$ & $25.18 \pm 1.20$ & $0.67 \pm 0.01^{\# \#}$ \\
\hline
\end{tabular}

Results are expressed as mean \pm SEM. $(n=6)$. Data was analysed by one way analysis of variance (ANOVA) followed by Tukey test. ${ }^{*} \# P<0.05$.

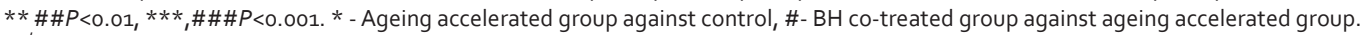


various biochemical and physiologic functions in most organs which leads to increased susceptibility to ageassociated neurodegeneration. ${ }^{33}$

The process of aging is accelerated by two important parameters i.e oxidative stress and reactive oxygen species (ROS). This two parameters are main cause for development of many age linked neurodegenerative diseases such as Alzheimer's and Parkinson's diseases. ${ }^{34}$ Many studies reported that, injecting the $\mathrm{D}$-galactose in brains of laboratory animals showed increase in formation of ROS, neuronal damage and a decline in learning and memory capacity., Moreover it has been reported that free radicals were increased in $\mathrm{D}$-galactose treated animals. ${ }^{35,36}$

Generation of oxidative stress is main mechanism by which $\mathrm{D}$-Galactose can induce aging. The oxygen metabolism of D-galactose produces many ROS. This ROS then directly or indirectly causes impairment of learning and memory. Advanced glycation endproducts (AGEs) are formed due to administration of D- galactose. Since D-galctose is a reducing sugar

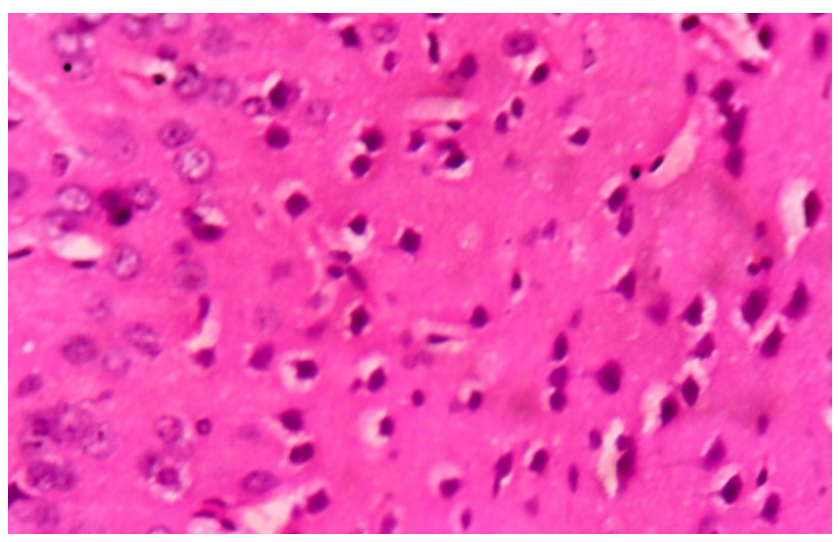

Figure 2: Saggital section of cerebral cortex of age accelerated mice demonstrating increased accumulation of lipofuscin granules.

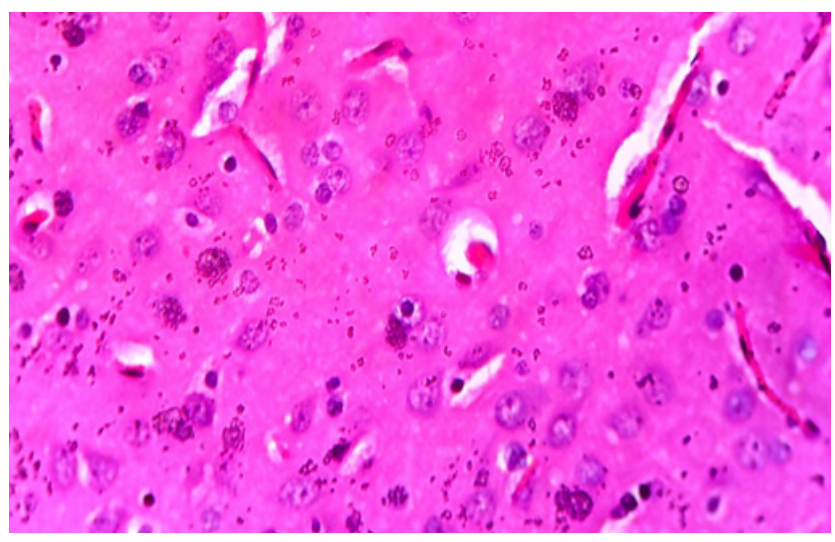

Figure 3: Saggital section of cerebral cortex of BHA cotreated mice demonstrating decreased of lipofuscin granules. that reacts readily with the free amine groups of amino acids in proteins and peptides both in vitro and in vivo. This reaction is mechanism of formation of advanced glycation end-products (AGEs). The chemical oxidation and degradation of AEGs, via AGE-receptor binding and activation of signaling pathways generates free radicals which causes the oxidative stress. Furthermore glycated protein produces fifty fold more free radicals than non glycated protein at the physiological $\mathrm{pH}$. This results in an increased oxidative stress and thereby damages to the micromolecules and cell organelles particularly the mitochondria, which is one of the sites of ROS formation. These affect the mitochondrial functioning causing less production of the ATP and still more production of the free radicals. Which in turn leads to an extra burden on lysosomes for the degradation of autophagocytosed and damaged micromolecules and mitochondria. ${ }^{5,6,10}$

In the present investigation, the administration of D-galactose in mice for 15 days, significantly $(P<0.001)$ increased the fluorescence product in cerebral cortex. There was a significant decrease in fluorescence product

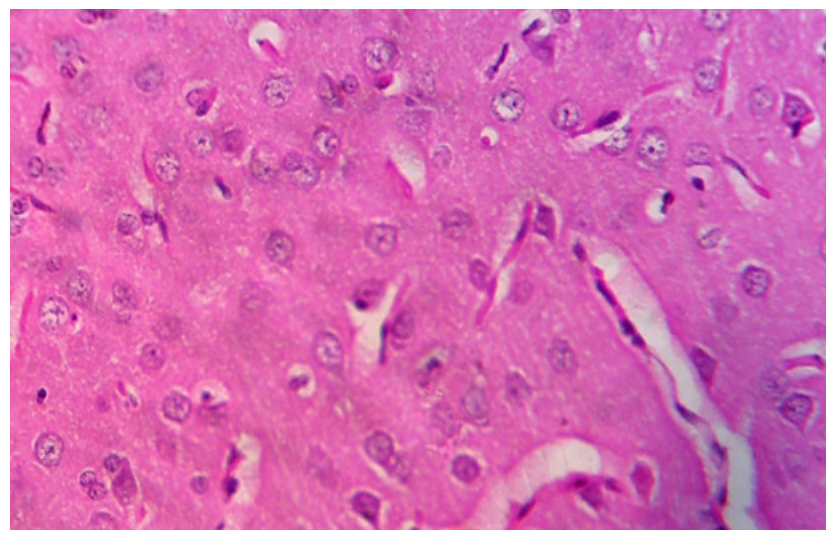

Figure 4: Saggital section of cerebral cortex of BHM cotreated mice.

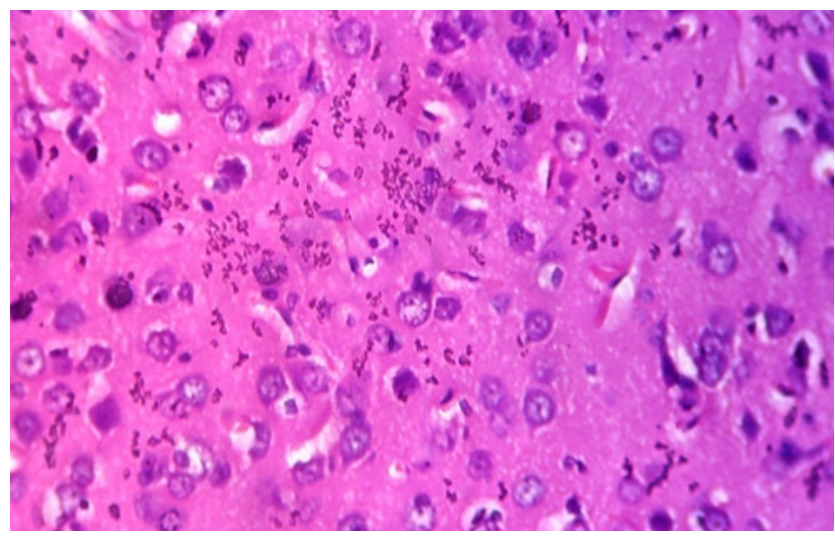

Figure 5: Saggital section of cerebral cortex of BHP cotreated mice. 
in cerebral cortex after cotreatment of BHA and BHM. Furthermore, the increased accumulation of lipofuscin granules were observed in brains of D-galactose treated aging accelerated group as compared to control. On contrary in BHM co-treated group, there were decrease accumulations of lipofuscin granules as compared to aging accelerated group.

Incresed level of Malondialdehyde is an indication of increased lipid peroxidation in $\mathrm{D}$ galactose treated mice that results due to increased oxidative stress. In $\mathrm{BH}$ co-treated mice, the MDA levels was significantly $(P<0.01)$ decreased as compare to ageing accelerated mice and these decreased may be due to inhibition of $\mathrm{D}$ galactose induced oxidative damage by $\mathrm{BH}$. The ROS can be scavenged by endogenous antioxidants including GPx and catalase. ${ }^{37}$ In this study, the activities of catalase and GPx in the cerebral cortex showed a statistically significant $(P<0.001)$ decline in model group mice compared to control group mice. Treatment with $\mathrm{BH}$ for two weeks significantly $(P<0.05)$ improve the activities of GPx and catalase.

Mitochondria causes more and more damage and cross linking of macromolecules by continuous production of free radicals. This includes enzymes and membrane components of lysosomes. Furthermore this process finally result in to an indigestible autofluorescent material commonly known as lipofuscin granules. ${ }^{11}$ In present investigation the administration of $\mathrm{D}$ galactose in mice for 15 days significantly $(P<0.001)$ increased the fluorescence product in cerebral cortex. Whereas in $\mathrm{BH}$ co-treated animals, significant decrease in fluorescence product in cerebral cortex was found which indicate its effectiveness against aging process.

\section{CONCLUSION}

BHM and BHA demonstrated significant neuroprotective activity by decreasing oxidative stress induced by D-galactose administration. The neuroprotective activity is though activation of catalase and glutathione peroxidase and consequently reducing lipid peroxide damage.

\section{ACKNOWLEDGEMENT}

Authors are thankful to Marathwada Mitra Mandals College of pharmacy for providing necessary facilities to conduct the research.

\section{CONFLICT OF INTEREST}

The authors declare no conflict of interests. The authors alone are responsible for the writing and contents of the paper.

\section{ABBREVIATIONS}

BHP: Petroleum ether extract Benincasa hispida; BHM: Methanolic extract Benincasa hispida; BHA: Aqueous extract of Benincasa hispida; ROS: Reactive Oxygen Species; AGE: Advanced glycation end-products; ATP: Adenosine triphosphate; BH: Benincasa hispida; HPTLC: High pressure thin layer chromatography; IAEC: Institutional Animal Ethics Committee; MDA: Malonaldialdehyde; TBRAS: Thiobarbituric acid reactive substances; GPx: Glutathione peroxidase; CAT: Catalase.

\section{REFERENCES}

1. Balaban RS, Nemoto S, Finkel T. Mitochondria, oxidants and aging. Cell. 2005;120(4):483 95 .

2. Peiris $H$, Dubach D, Jessup CF, Unterweger $P$, Raghupathi $R$, Muyderman $H$, et al. RCAN1 regulates mitochondrial function and increases susceptibility to oxidative stress in mammalian cells. Oxid Med Cell Longev. 2014;520316:112.

3. Kodeeswaran P, Michael HI, Kosta S, Carl AP. D-Galactose Effectiveness in Modeling Aging and Therapeutic Antioxidant Treatment in Mice. Rejuvenation Res. 2010;13(6):729-35.

4. Rattan SI. Aging is not a disease: Implications for intervention. Aging Dis. 2014;5(3):196-202.

5. Ambikar DB, Harle UN, Khandare RA, Bore VV, Vyawahare NS. Neuroprotective effect of hydroalcoholic extract of dried fruits of Trapa bispinosa Roxbon lipofuscinogenesis and fluorescence product in brain of D-galactose induced ageing accelerated mice. Indian J Exp Biol. 2010;48(4):378-82.

6. Ambikar DB, Mohanta GP. Neuroprotective effect of petroleum ether, methanolic and aqueous extracts of flower heads of Sphaeranthus indicus on lipofuscinogenesis and fluorescence product in brain of D-galactose induced aging accelerated mice. Orient Pharm Exp Med. 2013;13(4):301-6.

7. Zhang Q, Li X, Cui X, Zuo P. D-galactose injured neurogenesis in the hippocampus of adult mice. Neurol Res. 2005;27(5):552-6.

8. Shen Y, Xu S, Wei W, Sun X, Yang J, Liu L, et al. Melatonin reduces memory changes and neural oxidative damage in mice treated with $D$ galactose. $J$ Pineal Res. 2002;32(3):173-8.

9. Lu J, Zheng YL, Luo L, Wu DM, Sun DX, Feng YJ. Quercetin reverses d-galactose induced neurotoxicity in mouse brain. Behav Brain Res. 2006;171(2):251-60.

10. Gajare KA, Deshmukh AA, Pillai MM. Neuroprotective activity of bacopamonneria Linn in lipofuscinogenesis and fluorescence product in brain of D-galactose induced ageing accelerated mice. J Cell Tissue Res. 2007;7(2):1167-72.

11. Gajare KA, Deshmukh AA, Pillai MM. Effect of Bacopa monniera extract on lysosomal membrane integrity in the brain and heart of $D$-galactose induced oxidative stressed mice. J Cell Tissue Res. 2006;6(2):815-8.

12. Vyawahare NS, Ambikar DB, Patil GT, Kamble PN, Chitte NS. Phytomedicine for neuroprotection. Elec J Pharmacol Ther. 2008;1:15-23.

13. Mao J, Huang S, Liu S, Feng XL, Yu M, Liu J, et al. A herbal medicine for Alzheimer's disease and its active constituents promote neural progenitor proliferation. Aging Cell. 2015;14(5):784-96.

14. Rahimi R, Abdollahi M. Herbal medicines for the management of irritable bowel syndrome: A comprehensive review. World J Gastroentero. 2012;18(7):589600 . 
15. Chopra RN, Nayar SL, Chopra IC. Glossary of Indian Medicinal Plants (Including the Supplement). New Delhi: Council of Scientific and Industrial Research. 1986.

16. Sharma LK. Food Medicines. Practical Nature Cure. Pudukkottai: Natural Cure Publishing House. 1986.

17. Warier PK. Indian Medicinal Plants. Orient Longman Limited India. 1994.

18. Yoshizumi S, Murakami T, Kadoya M, Matsuda H, Yamahara J, Yoshikawa M. Medicinal food stuffs. XI. Histamine release inhibitors from wax gourd, the fruits of Benincasa hispida Cogn.Yakugaku Zasshi. 1998;118(5):188-92.

19. Grover JK, Adiga G, Vats V, Rathi SS. Extracts of Benincasa hispida prevent development of experimental ulcers. J Ethnopharmacol. 2001;78(2-3):159_ 164.

20. Grover JK, Rathi SS, Vats V. Preliminary study of fresh juice of Benincasa hispida on morphine addiction in mice. Fitoterapia. 2001;71(6):707-9.

21. Lee HK, Choi HR, Kim HC. Anti-angiogenic effect of the seed extract of Benincasa hispida Cogniaux. J Ethnopharmacol. 2005;97(3):509-13.

22. Ambikar DB, Mohanta GP. Effect of dried fruit extract of Benincasa hispidaon brain behabiour in laboratory animals. J Cell Tissue Res. 2013;13(1):3519-24.

23. Tyler VE, Brady LR, Robbers JE. Pharmacognosy. 9th edn. Lea and Fabiger, Philadelphia.1996.

24. Rachchh MA, Jain SM. Gastroprotective effect of Benincasa hispida fruit extract. Indian J Pharmacol. 2008;40(6):271-5.

25. Organization for Economic Co-operation and Development (OECD) Guidelines for Testing of Chemicals, acute oral toxicity studies. 2008.

26. Kakkar P, Das B, Viswanathan PN. A modified spectrophotometric assay of superoxide dismutase. Indian J Biochem Biophys. 1984;21:130-2.
27. Rotruck AJT, Pope AL, Ganther HE, Swanson AB, Hafeman DG, Hoekstra WG. Selenium: Biochemical role as a component of glutathione peroxidase. Science. 1973;179(4073):588-90.

28. Weandel A. Glutathione peroxidase. Methods Enzymol. 1981;77:325-33.

29. Mannervik B. Glutathione peroxidase. Methods Enzymol. 1985;113:490-5.

30. Claiborne A. Catalase activity. Handbook of methods in oxygen radical research, Boca Raton: CRS Press. 1991.

31. Lowry OH, Roseberough NJ, Farr AL, Randall RJ. Protein measurement with folin-phenol reagent. J Biol Chem. 1951;193(1):265-75.

32. Troyer H. Pigments and minerals. In: Principles and Techniques of Histochemistry, Boston: Little Brown and Company. 1980.

33. Matsugo S, Kitagawa T, Minami S, Esashi Y, Oomura Y, Tokumaru S, et al. Age-dependent changes in lipid peroxide levels in peripheral organs, but not in brain, in senescence-accelerated mice. Neurosci Lett. 2000;278(1-2):1058.

34. Ames BN, Shigenaga MK, Hagen TM. Oxidants, antioxidants and the degenerative diseases of aging. P Natl Acad Sci USA. 1993;90(17):7915-22.

35. Cui X, Zuo P, Zhang Q, Li X, Hu Y, Long J, et al. Chronic systemic D-galactose exposure induces memory loss, neurodegeneration and oxidative damage in mice: protective effects of R-alpha-lipoic acid. J Neurosci Res. 2006;83(8):1584-90.

36. Song X, Bao M, Li D, Li YM. Advanced glycation in D galactose induced mouse aging model. Mech Ageing Dev. 1999;108(3):239-51.

37. Cini M, Fariello RG, Bianchetti A, Moretti A. Studies in lipid peroxidation in the rat brain. Neurochem Res. 1994;19(3):283-8.

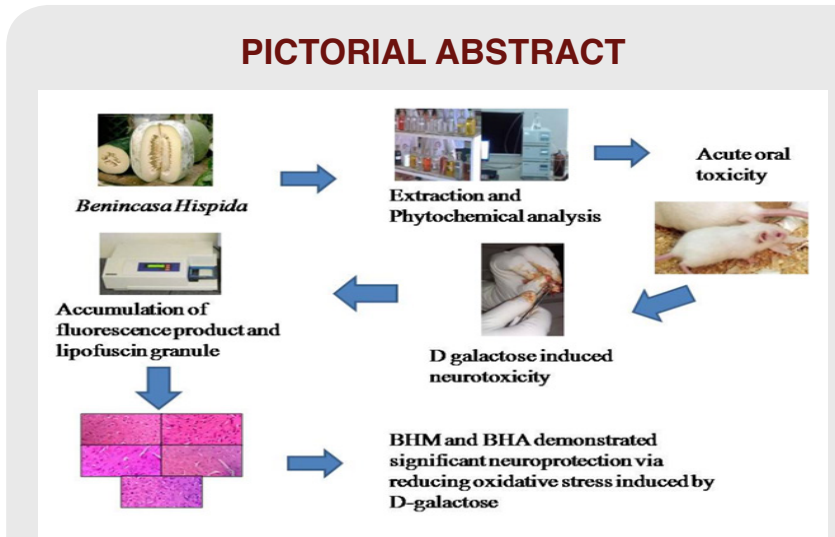

\section{SUMMARY}

Aging is a major cause for development of neurodegenerative disorders and loss of memory. Degenerative changes occurring in brain are irreversible. So neuroprotective drugs are ideal treatment for aging associated disorder. Due to unavailability of synthetic neuroprotective drug, research on plant drug is getting the popularity. $\mathrm{D}$ galactose induced age acceleration is well studied and validated model in laboratory animals. In our study we found that Benincasa hispida showed significant neuroprotective activity against $D$ galactose induced aging acceleration.

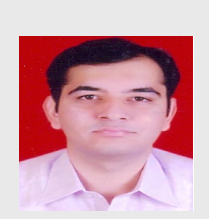

\section{About Authors}

Dr. Digambar Balkrishna Ambikar is having 13 years of experience of teaching to students of Pharmacy, Medicine, Nursing and Public health. He has 22 publication and 29 presentations to his credit. He received Young talent award by APP, 2019 and Gold medal-2008 to his PG research. He is known for his Pharmacology digital content for MBBS students preparing for various entrance and eligibility examinations.

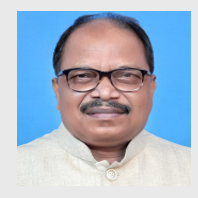

Dr. Guru Prasad Mohanta is Former Professor and Head, Department of Pharmacy, Annamalai University. He is the Vice-Chairman of Community Pharmacy Division of Indian Pharmaceutical Association. He is the recipient of the Best Researcher Award of Annamalai University in 2012 and IAPST Pharmaceutical Scientist of the year 2015 Award. He is a trainer in the area of Pharmaceutical Supply Management, Pharmacoeconomics and Rational Drugs Use.

Cite this article: Ambikar DB, Mohanta GP. Neuroprotective Effect of Petroleum Ether, Methanolic and Aqueous Extracts of Fruits of Benincasa hispida on Lipofuscinogenesis and Fluorescence Product in Brain of D-galactose Induced Aging Accelerated Mice. Indian J of Pharmaceutical Education and Research. 2021;55(2s):s528-s534. 